\title{
Vivat, vivat, vivat...
}

\section{Szanowni Państwo,}

jubileusz zawsze jest uroczystością szacowną. Jeśli zaś celebruje się ją w uniwersyteckim gmachu w obecności wielu znamienitych gości, to znaczenie chwili staje się jeszcze wyraźniejsze i inspiruje nie tylko do składania gratulacji, co oczywiście czynię, ale i do namysłu nad kwestiami zasadniczymi.

Dzisiejszy dzień jest przede wszystkim świętem Katedry Dydaktyki Języka i Literatury Polskiej, jest też jednak powodem do dumy dla całego środowiska dydaktycznego. Oto bowiem na Uniwersytecie Śląskim ukonstytuował się zespół zróżnicowany przecież, ale właśnie dzięki temu uświadamiający, jak ważna jest osobowościowo-sytuacyjna skuteczność pracy szkolnego i akademickiego polonisty. Konieczność uszanowania swobody osób uczących się i nauczających, pochwała umiaru i potrzeba metodycznej rozmaitości - to cechy wyłaniające się z wielu podejmowanych tu działań.

Sześćdziesiąt lat w życiu człowieka — to już trochę, w historii nauki — jednak niewiele, dlatego ważne jest i to, że podkreślanie znaczenia nauczycielskiej niezależności w katowickich publikacjach łączyło się z dążeniem do wyniesienia naszej młodej subdyscypliny do rangi scjencji. Dziedziny z natury rzeczy interdyscyplinarnej, łączącej świadomość kulturową z ustaleniami czynionymi w ramach pedagogiki czy filozofii nauczania, a także $\mathrm{z}$ wciąż ponawianym rozpoznawaniem postaw, oczekiwań, ale też zmieniających percepcyjnych możliwości i oczekiwań młodych czytelników literatury, użytkowników języka, odbiorców sztuk wizualnych.

Wieloaspektowość tych obserwacji przekonuje o niemożności zamknięcia zarówno edukacji, jak i rozważań jej dotyczących w obrębie jednego, nawet najlepszego systemu, a czynności polonistycznych w ramach jednej wybranej me- 
todologii. Jeśli traktujemy szkołę i uczelnię jako miejsce nie tylko kształcenia, badania, ale zwyczajnie - jako miejsce życia, to okazuje się ono znacznie bogatsze od indywidualnych rozstrzygnięć, doświadczeń, przekonań. W dydaktyce bowiem pasjonujące bywa to, że pozwala ona łączyć praktykę z jej uogólnionym opisem; to, co naukowe, z tym, co zdroworozsądkowe, to, co emocjonalne, z intelektualizacją obserwacji. Dychotomiczne, zdawałoby się, rozróżnienia nie tylko okazują się niesprzeczne, ale wręcz mogą się wzajemnie wspierać oraz inspirować do zwielokrotniania pytań. Taki sposób uprawiania nauki wydaje mi się największą zasługą dzisiejszej Katedry-Jubilatki i tego raz jeszcze gratuluję, i za to też w imieniu członkiń oraz członków zaprzyjaźnionej poznańskiej Pracowni Innowacji Dydaktycznych serdecznie dziękuję!

A że i dla nas dydaktyczna dychotomia ma spore znaczenie i cenimy sobie łączenie naukowej powagi naszej dyscypliny z niezbędnym w jej uprawianiu pulsowaniem nastroju, pracowniany chórek głosi dzisiaj taką oto pochwałę UŚ-u...

UŚ ma dzisiaj Jubileusz.

Ten nauki Koryfeusz

UŚ-wiadomi, coś UŚ-ciśli,

Nie UŚ-wierknie, a UŚ-liczni,

Raz z UŚ-miechem, raz UŚ-więci

I UŚ-wietni — ku pamięci...

Vivat, vivat, vivat $\mathbf{U} \mathbf{S} !$

UŚ to jest dopiero c-ÓŚ!!!!

Z wyrazami szacunku, w imieniu członkiń i członków

Pracowni Innowacji Dydaktycznych IFP UAM

Maria Kwiatkowska-Ratajczak

Poznań-Katowice, 17 czerwca 2019 roku 